\title{
Influence of Algal Bio-fertilizers on Fruit Lignification Time Interval, DNA Concentration and Agro-Morphological Characters in Okra (Abelmoschus Esculentus Moench)
}

\author{
Joyce F. Akpan ${ }^{1}$, Godwin M. Ubi ${ }^{2^{*}}$ and R. N. Njoku ${ }^{3}$ \\ ${ }^{1}$ Soil Microbiology Unit, Department of Soil Science, Faculty of Agriculture, Forestry and Wildlife \\ Resources Management, University of Calabar, Calabar, Nigeria. \\ ${ }^{2}$ Department of Genetics and Biotechnology, Faculty of Biological Sciences, University of Calabar, \\ Calabar, Nigeria. \\ ${ }^{3}$ National Root Crop Research Institute (NCRI), Umudike, Abia State, Nigeria.
}

Authors' contributions

This work was carried out in collaboration among all authors. Author GMU designed the study. Authors GMU and JFA performed the statistical analysis. Authors GMU and RNN wrote the protocol. Authors GMU and JFA wrote the first draft of the manuscript. Authors GMU and RNN managed the analyses of the study. Authors GMU and RNN managed the literature searches. All authors read and approved the final manuscript.

Article Information

DOI: $10.9734 / A R R B / 2020 / v 35 i 330201$

Editor(s):

(1) Dr. Viduranga Y. Waisundara, Australian College of Business and Technology, Sri Lanka.

Reviewers:

(1) M. V. N. L. Chaitanya, Dilla University, Ethiopia.

(2) Amit Kumar, Birsa Agricultural University, India.

(3) Paul Kweku Tandoh, Kwame Nkrumah University of Science and Technology, Ghana. Complete Peer review History: http://www.sdiarticle4.com/review-history/55170

Original Research Article

Received 08 January 2020

Accepted 13 March 2020

Published 14 May 2020

\section{ABSTRACT}

Experiment was set up in May to September, 2019 to evaluate the impact of algal bio-fertilizers on fruit lignification time interval, total genomic DNA contents, growth attributes as well as the yield components of three okra (Abelmoschus esculentus) (NHAE-47-4, NHAe-54-4 and Agwu early) genotypes sourced from NIHORT, Ibadan, Oyo State, Nigeria. The bio-fertilizers used for the study were a combination of cow dung + algae, poultry droppings + algae, Green Compost + algae and only soil as control. The test crops were sown into $50 \times 30 \times 25 \mathrm{~cm}^{3}$ perforated plastic buckets 
containing $5 \mathrm{~kg}$ of sterilized sandy loam soil and applied with the bio-fertilizers at $500 \mathrm{~g}$ each. The bio-fertilizers were prepared by using a combination of algae and organic manures. The experiment was a $3 \times 4$ experiment set up in completely randomized design (CRD) with 3 replications. Factor one was the Okra (Abelmoschus esculentus) genotypes with three levels (NHAe-47-4; NHAe-54-4 and Agwu early) while factor two was the different bio-fertilizers used with four levels (Cow dung + Algae; Polutry droopings + Algae; Green compost manure + Algae and soil as control). This gave a total treatment combination of 12 which was replicated thrice to give a total of 36 experimental units. Data for yield components were collected at maturity for days to flower initiation, number of seeds per pod, number of pods per plants and fresh fruit weight. Data generated from the study were collated and subjected to statistical analysis using the analysis of variance (ANOVA) procedures and significant treatment means were further separated using the Fishers' least significance difference test at 5 percent probability level. The results shows that genomic DNA contents varies from $134.100 \mathrm{ng} / \mu \mathrm{l}$ in Agwu early in control plot to $175.600 \mathrm{ng} / \mu \mathrm{l}$ in NHAe $-54-4$ treated with Poultry droppings +Algae. Fruit lignification time interval was significantly $(p<0.05)$ influenced by the bio-fertilizers and varied between 3 days 6 minutes in Agwu early in the control plots to 8 days and 23 hours in NHAe 47-4 treated with Poultry dropping + Alage. Plant height varied $(p<0.05)$ significantly and ranged from $14.13 \mathrm{~cm}$ in Agwu early in control plot to $44.34 \mathrm{~cm}$ in $\mathrm{NHAe}-47-4$ treated with Poultry droppings + Algae while number of fruits per plant also varied $(p<0.05)$ significantly and ranged between 12.57 fruits per plant in Agwu early in control plots to 24.30 fruits per plant in NHAe-47-4 treated with Poultry droppings + Algae. Hence, the study advocated for the use of poultry droppings + Algal bio-fertilizer in prolonging the fruit lignification time in okra for planned harvesting, increased income and mechanization of okra harvesting.

Keywords: Soil microbes; bio-fertilizers; fruit lignifications; growth and yield attributes; genomic DNA; okra.

\section{INTRODUCTION}

Okra, also known locally as 'Gombo', 'Ntonghi', 'Etighi' or lady's finger, is one of the crop plant used as vegetable for the longest time throughout history. The Ethiopians and Egyptians used it some millennium years ago. Today, Okra is grown primarily in the Tropical regions of Africa, Asia and America [1]. The fruit of okra is an annual herbaceous plant of the botanical family Malvaceae. It reaches a height of $1-5 \mathrm{~m}$ depending of cultivar. The fruits are greenish in color and covered with fine hairlike structure. The fruit has an elongated shape and its size ranges between $3-20 \mathrm{~cm}$. Okra is originally from Ethiopia from where its cultivation has extended throughout the hotter regions of the entire world. It is highly valued in the middle-east, India, East Africa, Nigeria, Thailand and the United States [2]. Okra is notable for its protein content which is quite high for a vegetable. In addition to its richness in vitamins and minerals, Okra fruits have remained a household recipe for the preparation of vegetable soup and other delicacies due to its high content of nutritious soluble mucilage which is locally believed to boost semen production in humans. Okra is also rich in soluble mucilage fibre which exercises a protective and emollient function within the digestive tract [3].
Okra has multiple health benefits. It is low in calories and contains no saturated fats or cholesterol and there is an ongoing research into its potential to manage diabetes. It can stabilize blood sugar levels by slowing it's absorption from the intestines. The pods are rich in mucilage; that thick gluey substance; it lubricates the large intestine and helps with elimination. Its rich content of vitamin c helps with body's immunity. The green pods contain beta carotene, lutein and xanthine with vitamin A [4]. They help preserve good vision and keep the skin fresh and healthy. It's been connected to cataract prevention and preventing spots and pimples. Other nutrients include thiamin, vitamin B6, niacin, phosphorus and copper. It is connected to cancer prevention especially colorectal cancer.

Despite the innumerable benefits of Okra, the fruits are known to initiate lignification and become hardened soon after the fruits formation [5]. The time interval between fruit formation and fruit hardening through lignification vary among Okra genotypes and depends on available mineral nutrients, environmental factors, moisture, pests and diseases. In most communities in Southern Nigeria, the lignified Okra fruits are processed into "Dried Okra" and preserved dried for future soup preparations. Although, this could be viewed as alternative way 
of utilizing Okra fruits that have been lignified, however, research have also shown that the mineral and nutritional composition and content of the fruit decreases with increase in lignin and fibre content of the fruits [6]. The dearth of information on fruit lignification time interval in Okra genotypes is an indication of the protracted decline in the cultivation and production of Okra by local farmers, thus making the large-scale production of the okra difficult.

Fruit lignification in Okra is a biochemical and physiological process which takes place inside the fruits resulting to the conversion of simple and soluble carbohydrates in the fruits to complex and insoluble carbohydrate polysaccharide compound called lignin which is deposited as dry matter within the cellulose cell walls of Okra during secondary thickening, thus conferring characteristics such hardiness, woodiness, toughening of tissues and rigidity of fruits making them resistant to tear and impermeable to water and gases [7]. This biochemical and physiological attribute of fruit lignification calls for the daily hand picking of small fruits, which are yet to attain physiological maturity and fruit size, thus making Okra production laborious and uneconomical. The biochemical and physiological processes leading to fruit lignification has made research efforts in Okra fruits much more difficult and thus left Okra vegetable fruit production to the local initiative of the resource poor farmers, despite the nutritional importance of the crop in human and animal dietary needs [8].

The attendant consequence of fruit lignification process in Okra and losses to Okra farmers cannot be overemphasized. According to Encyclopedia [9], fruit lignification in Okra has also defied conventional storage practices for fresh fruits and hence remains a source of concern for breeders, agronomists, horticulturists, nutritionist and farmers alike. The present study therefore seek to generate the much needed knowledge by researchers and farmers alike on ways of prolonging fruit lignification time interval for selected okra (Abelmoschus esculentus) genotypes through the use of bio-fertilizers to enable for adequate mechanization practices, planned harvesting of fresh fruits and large scale production of okra [10].

Thus, the present study thus intends to evaluate the role of bio-fertilizers on variations in fruit lignification time interval, DNA quantifications and agro-morphological attributes among three dwarf Okra genotypes in Calabar.

\section{MATERIALS AND METHODS}

\subsection{Study Location}

The study was carried out in Calabar during the vegetable cropping season in a compound garden at Esierebom, Calabar.

\subsection{Source of Experimental Materials}

Three dwarf, Early maturing okra genotypes; NHAe-47-4, NHAe-54-4 and Agwu early that was used in the study was collected from Nigerian horticultural Institute (NIHORT) Ibadan, Nigeria while the local varieties sourced from the Watt market.

\subsubsection{Sources of bio-fertilizers used for the studies}

Bio-fertilizers used for the study included algae which were sourced from piggery waste and pond water using algal plating techniques. Algal plating technique was used in isolating algal strains from waste pond water. The algal strains were isolated by modifying the methods of Alain, 2015. The isolated strains were sub-cultured in BG II medium under natural illumination of sunlight and subsequently sub cultured every seven days to maintain fresh algal culture. The isolates were purified by repeated streaking on solid media and identified to the genus level using standard laboratory procedures and reference materials.

Some of the identified algal strains isolated from the waste pond and piggery wastes water obtained from the University of Calabar farms included

1. Chlorella vulgaris

2. Chodatella species

3. Chlorella pyrenoides

4. Scenedemus obliques

Sodium bicarbonate was used as a carbon source for algal growth at the dose of $4 \mathrm{~g}$ per litre of the pond water in cow dung, poultry droppings and kitchen wastes compost as growth media and biofertilizer potting mix.

a. kitchen waste compost + Algae

b. Cow dung + Algae

c. Poultry droppings + Algae

d. Soil (Control) without algae 


\subsection{Experimental Design}

The experiment was set up in the compound garden field measuring $10 \mathrm{~m}$ x $5 \mathrm{~m}$. Each experimental unit was a plastic bucket containing the treatments. The experiment was laid out in a $3 \times 4$ factorial with 3 replications. The experimental setup was a Complete Randomized Design (CRD). The three early maturing okra genotypes planted on each plots, plot-to-plot distances will maintain at 1.25 and $0.75 \mathrm{~m}$ and line-to-line distance of $30 \mathrm{~cm}$.

\subsection{Experimental Model for Fruit Ligni- fication Time Interval Determination}

The basic Tenus and Michaelis-Mentens enzyme model was modified and adopted for the determination of time interval for fruit lignification in Okra. However, this was achieved with some basic assumptions which are stated below

$$
\delta \varepsilon=a \mu+b \delta \mu+k \varepsilon
$$

Assumptions here are that $\mathrm{a}, \mathrm{b}$ and $\mathrm{k}$ are model constants given in hours. Where $a$ and $b$ aregreater or equal to 24 hours

$\varepsilon=$ specific rate of dry matter or mineral accumulation in Okra fruit

$\mu=$ fruit specific growth rate

$\delta=$ change or differential

$\mathrm{T}=$ fruit lignification time interval in hours

For this present study, the model was not adopted because of lack of equipment for determining rate of dry matter accumulation and growth rate of fruit.

\subsection{Direct Timing and Measurement of Lignification Time Interval}

This method was adopted for the measurement of time interval for fruit lignification for thedifferent okra genotypes throughout the duration of the experiment as described below.

[Fruit Lignification Time Interval = Final Time of Fruit Lignification - Initial Time of Fruit Formation]

$$
[F L T I=F T F L-I T F F]
$$

\subsection{Extraction of Genomic DNA from Samples}

This was carried out in the molecular biology laboratory of the Department of Genetics and Biotechnology, University of Calabar. The total genomic DNA for the samples was isolated from the fruits of okra plants for each treatment following a modified CTAB method. DNA samples were extracted from the leaves by removing a fruit disc of each cultivar using the lid of a $1.5 \mathrm{ml}$ microfuge tube and flash frozen in liquid nitrogen $\left(-196^{\circ} \mathrm{C}\right)$. The frozen fruit tissues were then quickly grounded to a fine powder using a micropestle followed by addition of 1-2 $\mu \mathrm{L}$ of RNase from stock solution $\left(10 \mathrm{mg} \mathrm{ml}^{-1}\right.$ ) to $1 \mathrm{ml}$ of extraction buffer. Before thawing the samples, $600 \mu \mathrm{L}$ aliquot of the extraction buffer was added to each of the tissue samples. The samples were vortexed on a vortex mixer for three seconds and incubated in a water bath at $45^{\circ} \mathrm{C}$ for $15 \mathrm{~min}$.

Samples were then centrifuged for 2 min (13000 $\mathrm{rpm}) .500 \mu \mathrm{l}$ of the supernatant was drawn using

Table 1.Experimental layout

\begin{tabular}{lllll}
\hline Factor A & Factor B & Rep 1 & Rep 2 & Rep 3 \\
\hline NHAe-47-4 & Cow dung + Algae (B1) & A1B1 & A2B4 & A2B4 \\
(A1) & Poultry droppings + Algae (B2) & A1B2 & A2B2 & A2B3 \\
& Green Compost manure + Algae (B3) & A1B3 & A1B4 & A3B4 \\
& Soil (B4) & A1B4 & A2B3 & A3B3 \\
NHAe -54-4 & Cow dung + Algae (B1) & A2B1 & A3B2 & A3B1 \\
(A2) & Poultry dropping + Algae (B2) & A2B2 & A1B1 & A1B1 \\
& Green Compost manure + Algae (B3) & A2B3 & A3B1 & A1B3 \\
& Soil (B4) & A2B4 & A3B4 & A2B1 \\
Agwu Early & Cow dung + Algae (B1) & A3B1 & A3B3 & A3B2 \\
(A3) & Poultry dropping + Algae (B2) & A3B2 & A2B1 & A2B2 \\
& Green Compost manure + Algae (B3) & A3B3 & A1B3 & A1B2 \\
& Soil (B4) & A3B4 & A1B2 & A1B4 \\
\hline
\end{tabular}


a micropipette $(1 \mathrm{ml})$ and transferred to a new microfuge tube and $500 \mu$ of ice cold isopropanol was added to the supernatant. The original microfuge tube containing the fruit tissue was discarded. The supernatant was then incubated on ice for $5 \mathrm{~min}$ followed by centrifugation for 5 min. After centrifuging, the supernatants were drawn by a micropipette and discarded and 600 $\mu \mathrm{l}$ of ethanol $(70 \% \mathrm{v} / \mathrm{v})$ and centrifuged again for $3 \mathrm{~min}$. The supernatants were discarded as described previously and the pellets air-dried in a laminar airflow bench and the pellets resuspended for 15-20 min later in DNase free water $(50 \mu \mathrm{l})$.

\subsection{DNA Quantification}

The extracted genomic DNA was quantified using the Nanodrop 1000 spectrophotometer. The software of the equipment was launched by double clicking on the Nanodrop icon. The equipment was initialized with 2 ul of sterile distilled water and blanked using normal saline solution. Two microliter of the extracted DNA was loaded into the lower pedestal, the upper pedestal was brought down to contact the extracted DNA on the lower pedestal. The DNA concentration was measured by clicking on the "measure" button and subsequently recording the readings. All readings and measurements were taken at 260/280 nM wavelengths.

\subsection{Data Collection Procedures}

The experiment was located and carried out in compound garden and backyard to facilitate easy access to test crops at odd hours of the night, observations and time measurement. Fruit lignification interval was obtained by recording the time interval between fruit formation (newly formed fruits) and fruit hardening per plant. Daily recording of time interval and number of new fruits formed and their time of hardening was recorded for each treatment. Data was also be collected for growth and yield attributes are as follows;

\subsubsection{Growth attributes}

i. Plant height $(\mathrm{cm})$

ii. Leaf length $(\mathrm{cm})$

iii. Leaf width $\left(\mathrm{cm}^{2}\right)$

iv. Leaf area $\left(\mathrm{cm}^{2}\right)$

V. Number of branches per plant

\subsubsection{Yield attributes}

i. Number of fruits per plant

ii. Number of seed per fruit iii. Fresh weight of fruit per plot $(\mathrm{g})$

iv. Dry weight of fruit per plot $(\mathrm{g})$

v. Okra fruit yield ( $\mathrm{kg} / \mathrm{ha})$

\subsection{Data Analysis}

Growth yield or data generated from the study was collated and subjected to Analysis of Variance (ANOVA) procedure following the Completely Randomized Design (CRD) procedures. Significant treatment means were separated using Fischer's Least Significant Different (LSD) at $5 \%$ probability levels. The Genstat 15.1 software was employed for the analysis of the generated data.

\section{RESULTS}

\subsection{Influence of Algal Bio-fertilizers on Total Genomic DNA Concentration and Quantification in Okra Genotypes as Read from Nanodrop Spectro- photometer}

The extracted genomic DNA after quantification using Nanodrop spectrophotometer at 260/280 $n m$ reveals that significant $(P<0.05)$ differences were detected in the total genomic DNA concentrations in the selected okra genotypes as influenced by the applications of bio-fertilizers (Table 2). The genomic DNA concentration varied from $127.700 \mathrm{ng} / \mu \mathrm{l}$ in NHAE-47-4 treated with poultry dropping + algae to $129.900 \mathrm{ng} / \mu \mathrm{l}$ in $\mathrm{NHAe}-47-4$ treated with kitchen wastes +algae.NHAe-47-4 treated with cow dung + algae had a genomic DNA quantification of $129.800 \mathrm{ng} / \mu \mathrm{l}$ while $\mathrm{NHAe}-47-4$ in the control plot without bio-fertilizer had DNA concentration of $128.700 \mathrm{ng} / \mu \mathrm{l}$. NHAe-54-4 okra genotype treated with cow dung + algae had total genomic DNA concentration of $176.600 \mathrm{ng} / \mu \mathrm{l}$ while same genotype treated with poultry droppings + algae produced total genomic DNA of $176.800 \mathrm{ng} / \mu \mathrm{l}$. $\mathrm{NHAe}-54-4$ treated with kitchen wastes + algae and soil (control) produced total genomic DNA quantities of 174.600 and $175.400 \mathrm{ng} / \mathrm{\mu l}$ respectively. The total genomic DNA concentrations in Agwu early local cultivar as influenced by bio-fertilizers was also evaluated and the results showed that treatment of the cultivar with cow dung + algae, poultry droppings + algae, kitchem wastes + algae and soil (control) generated total genomic DNA quantities of $134.400 \mathrm{ng} / \mu \mathrm{l}, 134.700 \mathrm{ng} / \mathrm{\mu l}, 134.650 \mathrm{ng} / \mu \mathrm{l}$ and $134.390 \mathrm{ng} / \mu \mathrm{l}$ respectively. NHAe $-54-4$ had the highest genomic dNA concentrations while 
Agwu early had the least genomic DNA concentrations.

\subsection{Influence of Algal Bio-fertilizers in Prolonging Fruit Lignification Time Interval in Three Okra Genotypes}

The results of the influence of bio-fertilizer on the fruit lignificantion time interval in three okra genotypes are presented in Table 2. The results indicate that the three okra genotypes differ $(P$ $<0.05)$ significantly in their fruit lignification time interval. The application of cow dung + algae biofertilizer treatment to the three okra genotypes shows that it took a lignification time interval of 6 days 23 hours in Agwu early, 7 days 6 minutes in NHAe-54-4 and 7 days 30 minutes. Application of poultry dropping + algae to the three okra genotypes produced the longest fruit lignification interval of 8 days 66 minutes in NHAE-47-4, 8 days 84 minutes in NHAe-54-4 and took 8 days 24 minutes for the fresh fruits of Agwu early to be lignified. When treated with kitchen wastes + algae treatment, NHAe-47-4, NHAe -57-4 and Agwu early fresh fruits required 6 days 6 minutes, 6 days 30 minutes and 5 days 23 hours to become lignified respectively. Okra genotypes planted in the control plots did not receive any bio-fertilizer treatment but only soil. The fruit lignification time for the measured from the control plots for $\mathrm{NHAe}-47-4$ is $s$ days 6 minutes, for $\mathrm{NHAe}-54-4$ is 3 days 4 hours and 18 minutes while Agwu early fruits required 3 days 6 hours to become lignified.

Table 2. Influence of algal bio-fertilizers on total genomic DNA concentrations in early maturing okra (Abelmoschus esculentus) genotypes

\begin{tabular}{|c|c|c|}
\hline Okragenotypes & Bio-fertilizer treatments & 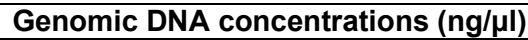 \\
\hline & Cowdung + Algae $\left(\mathrm{B}_{1}\right)$ & 129.800 \\
\hline$A_{1}$ & Poultry dropping + Algae (B2) & 127.700 \\
\hline \multirow[t]{2}{*}{ NHAe-47-4 } & Green compost manure +Algae (B3) & 129.900 \\
\hline & Soil (Control) (B4) & 128.700 \\
\hline$A_{2}$ & Cowdung + Algae $\left(\mathrm{B}_{1}\right)$ & 176.600 \\
\hline \multirow[t]{3}{*}{ NHAe-54-4 } & Poultry dropping + Algae (B2) & 176.800 \\
\hline & Green compost manure +Algae (B3) & 174.600 \\
\hline & Soil (control) (B4) & 175.400 \\
\hline $\mathrm{A}_{3}$ & Cowdung + Algae $\left(\mathrm{B}_{1}\right)$ & 134.400 \\
\hline \multirow[t]{3}{*}{ Agwu Early } & Poultry dropping + Algae (B2) & 134.700 \\
\hline & Green compost manure +Algae (B3) & 135.650 \\
\hline & Soil (Control) (B4) & 134.390 \\
\hline
\end{tabular}

Table 3. Means and standard errors of fruit lignification time interval for dwarf early maturing okra (Abelmoschus esculentus) genotypes fruit lignification time interval of Okra genotypes treated with algal bio-fertilizers

\begin{tabular}{llll}
\hline Okragenotypes & Bio-fertilizer treatments & $\begin{array}{l}\text { Fruit lignification time } \\
\text { interval (Hours) }\end{array}$ & $\begin{array}{l}\text { Fruit lignification time } \\
\text { interval (Days) }\end{array}$ \\
\hline NHAe-47-4 (A1) & Cowdung + Algae & $168.25 \mathrm{~b} \pm 3.50$ & 7.10 days \\
NHAe-54-4 (A2) & Cowdung + Algae & $169.25 \mathrm{~b} \pm 3.40$ & 7.05 days \\
Agwu Early (A3) & Cowdung + Algae & $167.50 \mathrm{~b} \pm 3.22$ & 6.98 days \\
NHAe-47-4 (A1) & Poultry dropping + Algae & $194.75 \mathrm{a} \pm 3.45$ & 8.11 days \\
NHAe-54-4 (A2) & Poultry droppings + Algae & $195.50 \mathrm{a} \pm 2.30$ & 8.14 days \\
Agwu Early (A3) & Poultry dropping + Algae & $192.90 \mathrm{a} \pm 1.50$ & 8.03 days \\
NHAe-47-4 (A1) & Green compost manure & $144.25 \mathrm{c} \pm 2.45$ & 6.01 days \\
& +Algae & & 6.05 days \\
NHAe-54-4 (A2) & Green compost manure & $145.50 \mathrm{c} \pm 1.20$ & 5.95 days \\
& +Algae & & 3.01 days \\
Agwu Early (A3) & Green compost manure & $142.75 \mathrm{c} \pm 3.25$ & 3.27 days \\
& +Algae & $72.40 \mathrm{~d} \pm 1.50$ & 3.10 days \\
NHAe-47-4 (A1) & Soil (Control) & $78.50 \mathrm{~d} \pm 5.40$ & \\
NHAe-54-4 (A2) & Soil (control) & $74.25 \mathrm{~d} \pm 3.14$ & 12.40 \\
Agwu Early (A3) & Soil (Control) & & \\
LSD (0.05) & & ${ }^{*}$ Data are means and standard errors of three (3) replicates
\end{tabular}




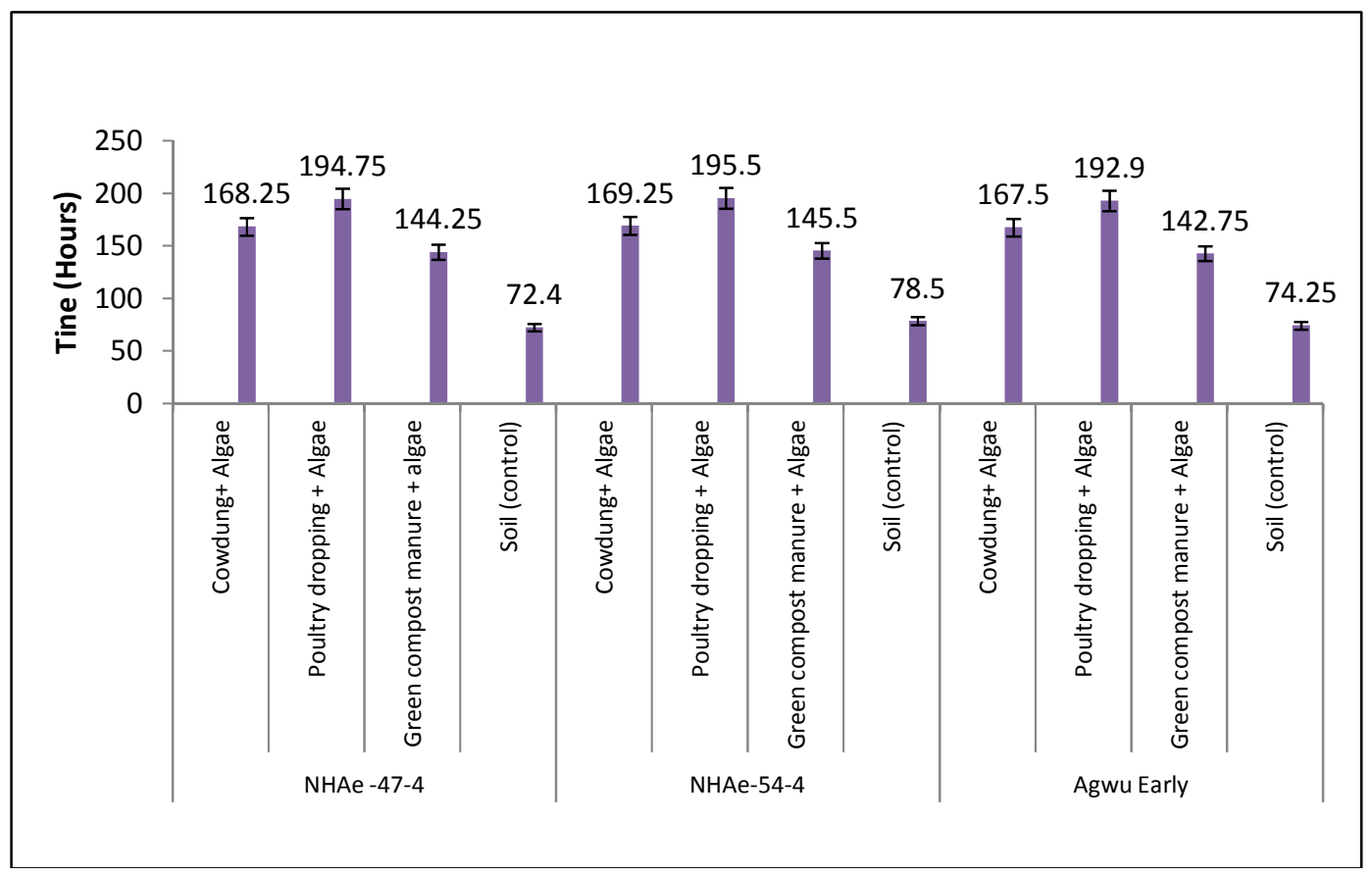

Fig. 1. Fruit lignification time interval of okra genotypes under different Algal biofertilizers treatment

\subsection{Influence of Bio-fertilizers on Growth Characteristics of the Three Okra Genotypes}

The results of the influence of algal bio-ferilizers on the growth characteristics of three okra genotypes are presented in Table 3 . The leaf area, leaf width and plant height were significantly influenced among the okra genotypes by the bio-fertilizers while the number of leaves per plant, number of branches per plant and leaf length per plant did not vary amongst the treatments and their interactions. The leaf area varied from $96.23 \pm 1.20 \mathrm{~cm}^{2}$ in Agwu early planted in the control plots to $136.56 \pm 10.20$ $\mathrm{cm}^{2}$ in NHAe-47-4 treated with cow dung + algae. Leaf width ranged from $4.69 \pm 0.57 \mathrm{~cm}$ in $\mathrm{NHAe}$ $54-4$ in the control plot to $12.18 \pm 1.20 \mathrm{~cm}$ in $\mathrm{NHAe}-47-4$ treated with poultry dropping + algae. The tallest okra plants which measured $44.34 \pm 0.57 \mathrm{~cm}$ were obtained from NHAe-47-4 treated with cow dung + algae while the shortest okra plant which measured $24.13 \pm 1.20 \mathrm{~cm}$ was obtained from Agwu early cultivar in the control plot. The number of leaves per plant varied from $3.01 \pm 1.88$ in Agwu early genotype in control plots to $9.98 \pm 1.57$ in NHAe-54-4 treated with kitchen wastes + algae. The number of branches per plant ranged from $2.89 \pm 1.20$ in Agwu early in control plots to $4.61 \pm 1.20$ in NHAe-47-4 treated with poultry droppings + algae. The leaf length varied from $7.82 \pm 1.20 \mathrm{c}$ min Agwu early in control plots to $16.60 \pm 2.20 \mathrm{~cm}$ in NHAe-54-4 treated with kitchen wastes + algae.

\subsection{Influence of Bio-fertilizers on Yield Components of the Three Okra Genotypes}

The results of the influence of bio-ferilizers on the yield components of three okra genotypes is presented in Table 4. The days to flower initiation, fruit length and number of fruit per plant were significantly influenced among the okra genotypes by the bio-fertilizers while the fruit width and fruiting interval did not vary amongst the treatments and their interactions. The days to flower initiation varied from $16.00 \pm 1.20$ days in $\mathrm{NHAe}-47-4$ treated with cow dung + algae to $23.00 \pm 1.20$ days for Agwu early planted in the control plots. Fruit length ranged from $4.18 \pm 1.20$ $\mathrm{cm}$ in NHAe-47-4 to $9.18 \pm 1.57 \mathrm{~cm}$ in NHAe-54-4 treated with kitchen wastes + algae. Fruit width measured $2.22 \pm 1.20 \mathrm{~cm}$ in Agwu early in control plots and $3.96 \pm 0.57 \mathrm{~cm}$ in NHAe-47-4 treated with cow dungs + algae. The number of fruits per plant varied from $12.57 \pm 1.88$ in Agwu early genotype planted in control plots to $24.30 \pm 1.20$ in $\mathrm{NHAe}-47-4$ treated with poultry droppings + algae. Fruiting interval results for the genotypes 
Table 4. Means and Standard errors of some growth attributes for dwarf early maturing okra (Abelmoschus esculentus) genotypes treated with algal bio-fertilizers

\begin{tabular}{lllllll}
\hline Genotypes & $\mathbf{L A}\left(\mathbf{c m}^{\mathbf{2}}\right)$ & $\mathbf{L W}(\mathbf{c m})$ & $\mathbf{L P P}(\mathbf{m})$ & $\mathbf{B P P}$ & $\mathbf{L L}(\mathbf{c m})$ & $\mathbf{P H}$ \\
\hline A1B1 & $126 \mathrm{~b} \pm 4.0$ & $6.47 \mathrm{bc} \pm 0.04$ & $8.91 \pm 0.50$ & $4.61 \pm 0.14$ & $13.3 \pm 0.20$ & $32.75 \mathrm{bc} \pm 2.12$ \\
A1B2 & $129 \mathrm{ab} \pm 6.0$ & $5.21 \mathrm{c} \pm 0.20$ & $7.66 \pm 0.80$ & $3.87 \pm 0.07$ & $12.6 \pm 0.10$ & $38.76 \mathrm{~b} \pm 0.30$ \\
A1B3 & $132 \mathrm{a} \pm 3.0$ & $12.69 \pm 0.03$ & $8.79 \pm 0.23$ & $3.91 \pm 0.11$ & $12.4 \pm 0.10$ & $44.34 \mathrm{a} \pm 0.57$ \\
A1B4 & $136 \mathrm{~b} \pm 10.0$ & $4.18 \mathrm{a} \pm 1.04$ & $3.98 \pm 0.50$ & $3.74 \pm 0.04$ & $13.2 \pm 2.0$ & $39.31 \mathrm{ab} \pm 3.98$ \\
A2B1 & $121 \mathrm{c} \pm 15.0$ & $7.89 \mathrm{~b} \pm 0.80$ & $7.50 \pm 0.09$ & $3.61 \pm 0.47$ & $12.4 \pm 3.0$ & $37.32 \mathrm{~b} \pm 0.88$ \\
A2B2 & $132 \mathrm{a} \pm 12.0$ & $6.11 \mathrm{~b} \pm 0.13$ & $6.61 \pm 0.22$ & $3.59 \pm 0.89$ & $14.8 \pm 1.0$ & $29.05 \mathrm{c} \pm 1.00$ \\
A2B3 & $98 \mathrm{~d} \pm 10.0$ & $12.18 \mathrm{a} \pm 1.04$ & $9.98 \pm 0.50$ & $3.74 \pm 0.04$ & $16.6 \pm 2.0$ & $29.54 \pm 1.56$ \\
A2B4 & $121 \mathrm{c} \pm 15.0$ & $7.89 \mathrm{~b} \pm 0.80$ & $8.50 \pm 0.09$ & $3.61 \pm 0.47$ & $12.9 \pm 3.0$ & $37.44 \mathrm{~b} \pm 2.44$ \\
A3B1 & $128 \mathrm{a} \pm 12.0$ & $6.11 \mathrm{~b} \pm 0.13$ & $7.61 \pm 0.22$ & $3.59 \pm 0.89$ & $14.3 \pm 1.0$ & $29.87 \mathrm{c} \pm 3.12$ \\
A3B2 & $98 \mathrm{~d} \pm 10.0$ & $7.18 \mathrm{a} \pm 1.04$ & $8.98 \pm 0.50$ & $3.74 \pm 0.04$ & $16.4 \pm 2.0$ & $29.32 \mathrm{c} \pm 0.57$ \\
A3B3 & $121 \mathrm{c} \pm 15.0$ & $7.89 \mathrm{~b} \pm 0.80$ & $9.50 \pm 0.09$ & $3.61 \pm 0.47$ & $12.5 \pm 3.0$ & $37.03 \mathrm{~b} \pm 0.88$ \\
A3B4 & $96 \mathrm{a} \pm 12.0$ & $6.11 \mathrm{~b} \pm 0.13$ & $8.61 \pm 0.22$ & $2.59 \pm 0.89$ & $7.8 \pm 1.0$ & $24.13 \mathrm{c} \pm 1.02$ \\
LSD & $\mathbf{4 . 3 4}$ & $\mathbf{2 . 7 3}$ & $\mathbf{N S}$ & $\mathbf{N S}$ & $\mathbf{N S}$ & $\mathbf{4 . 9 8}$ \\
\hline
\end{tabular}

Data are means and standard errors of five (3) replications.

$N S=$ Not significant at $(p<0.05) ; L A=$ Leaf area $\left(\mathrm{cm}^{2}\right) ; L W=$ Leaf width $(\mathrm{cm}) ; L L=$ Leaf length $(\mathrm{cm}) ; P H=$ plant height $(\mathrm{cm})$; $B P P=$ Branches per plant; $L P P=L$ eaves per plant

Table 5. Means and Standard errors of some yield attributes for dwarf early maturing okra (Abelmoschus esculentus) genotypes treated with Algal bio-fertilizers

\begin{tabular}{llllll}
\hline Trt. Combination & DFI & FL $(\mathbf{c m})$ & FW $(\mathbf{c m})$ & FPP & FI (Days) \\
\hline A1B1 & $16 \mathrm{~b} \pm 4.0$ & $6.47 \mathrm{~b} \pm 0.04$ & $3.91 \pm 0.50$ & $24.3 \mathrm{a} \pm 1.88$ & $22 \pm 0.88$ \\
A1B2 & $19 \mathrm{ab} \pm 6.0$ & $5.21 \mathrm{~b} \pm 0.20$ & $3.66 \pm 0.80$ & $21.5 \mathrm{~b} \pm 0.32$ & $18 \pm 1.00$ \\
A1B3 & $22 \mathrm{a} \pm 3.0$ & $8.69 \mathrm{~b} \pm 0.03$ & $3.01 \pm 0.23$ & $10.91 \mathrm{f} \pm 0.72$ & $19 \pm 0.57$ \\
A1B4 & $18 \mathrm{~b} \pm 1.0$ & $4.18 \mathrm{a} \pm 1.04$ & $2.98 \pm 0.50$ & $16.34 \pm 1.50$ & $19 \pm 1.08$ \\
A2B1 & $21 \mathrm{c} \pm 1.0$ & $7.89 \mathrm{ab} \pm 0.80$ & $2.50 \pm 0.09$ & $18.21 \mathrm{f} \pm 1.34$ & $17 \pm 0.57$ \\
A2B2 & $22 \mathrm{a} \pm 1.0$ & $6.11 \mathrm{~b} \pm 0.13$ & $2.61 \pm 0.22$ & $19.65 \mathrm{c} \pm 1.04$ & $16 \pm 1.00$ \\
A2B3 & $23 \mathrm{~b} \pm 1.0$ & $9.18 \pm 1.04$ & $2.98 \pm 0.50$ & $16.32 \mathrm{~d} \pm 1.57$ & $18 \pm 0.03$ \\
A2B4 & $21 \mathrm{c} \pm 1.0$ & $5.89 \mathrm{a} \pm 0.80$ & $2.50 \pm 0.09$ & $12.98 \mathrm{e} \pm 0.70$ & $17 \pm 1.28$ \\
A3B1 & $22 \mathrm{c} \pm 0.57$ & $6.11 \mathrm{~b} \pm 0.13$ & $2.61 \pm 0.22$ & $19.66 \mathrm{c} \pm 0.30$ & $16 \pm 1.34$ \\
A3B2 & $18 \mathrm{~b} \pm 1.0$ & $9.18 \mathrm{a} \pm 1.04$ & $2.98 \pm 0.50$ & $16.57 \mathrm{~d} \pm 1.22$ & $18 \pm 1.32$ \\
A3B3 & $21 \mathrm{c} \pm 1.0$ & $7.89 \mathrm{a} \pm 0.80$ & $2.50 \pm 0.09$ & $19.40 \mathrm{e} \pm 2.03$ & $17 \pm 1.76$ \\
A3B4 & $23 \mathrm{c} \pm 1.0$ & $6.11 \mathrm{~b} \pm 0.13$ & $2.22 \pm 0.22$ & $12.57 \mathrm{c} \pm 0.57$ & $14 \pm 0.88$ \\
LSD & $\mathbf{3 . 2 5 ^ { * }}$ & $\mathbf{2 . 0 1 *}$ & $\mathbf{N S}$ & $\mathbf{1 . 1 4}$ & $\mathbf{N S}$ \\
\hline
\end{tabular}

Data are means and standard errors of three (3) replications.

$N S=$ Not significant at $(p<0.05) ; D F I=$ days to flower initiation; $P F=$ period of fruiting; $F P P=$ fruits per plant; $P H=$ plant height $(m) ; B P P=B r a n c h e s$ per plant; $F L=F r u i t$ length $(\mathrm{cm}) ; F W=$ Fruit width $(\mathrm{cm}) ; F I=$ Fruiting Interval (Days)

shows that Agwu early genotype in the controil plots produced fruits for a period of $14 \pm 0.88$ days while $22 \pm 1.20$ days was the numbers of days used by NHAe-47-4 treated with cow dung + algae to produced fruits.

\section{DISCUSSION}

The study revealed that okra genotypes treated with bio-fertilizer takes longer time to become lignified and long period of fruiting compared to okra genotypes planted in control plots without the bio-fertilizers. NHAe-47-4 and "NHAe-54-4" developed fruits with prolong time before lignification compared to Agwu early which showed shorter time interval to become lignified and a shorter period of fruiting. The study report finding is in line with the reports of Muhammad et al. [11]. Knowledge of fruit lignification time interval in Okra will no doubt reduce the laborious task of daily handpicking of immature fruits, reduce the rate of spoilage of the vegetable, enable for the consumption of fresh rather than dried okra and for plan and controlled harvesting of fruits for the market, income to the farmers and ensure food security [12].

Organic manure and biofertilizers have been reported to impact significantly crop growth and yield. This has been made possible due of the 
mineralization role, organic manure and biofertilizers play in soil development and plant soil nutrient relationship. The rate of lignification is greatly reduced in soils with adequate availability of basic macro and micro nutrients which are the primary nutrient for plant growth and development [11,12]. Thus biofertilization and organic manuring have been found to reduce fruit lignification in this present study. The treatments have also been responsible for increased growth and yield attributes recorded in the okra genotypes treated with the biofertilizers over the control.

In a similar study, in which early maturing and late maturing Okra genotypes were separated due to the differences in their life span, [12] reported that the dwarf early maturing genotypes are ephemeral in nature (that is) short life span of not more than three months while the tall, late maturing genotypes are annual in their life span. The reports and findings revealed that the early maturing genotypes which are normally cultivated two or thrice a year in irrigated areas has shorter time interval to become unusable in their fresh conditions while the late maturing genotypes which are normally not often cultivated because of their long period of nurturing, has longer time interval for fruits to become lignified. This calls for an improvement of the early maturing, dwarf genotypes in terms of prolonging their fruits lignification time interval so as to yield more economic returns to the farmers [12,13]. As breeders, the identification of the genes responsible for fruit lignification in Okra through the use of molecular markers and other marker assisted breeding and protocols is strongly advocated.

The identification of the responsible gene(s) and the genetic engineering (isolation and stable incorporation of the desired gene(s) of interest) to the genome of other genotypes with short fruit lignification time interval, develop and distributes to farmers for use will reduce the wastage and loss associated with fruit lignification in Okra $[14,15]$.

The study tried to express the duration of time for dry matter or mineral accumulation in the fruits of okra which confers rigidity, hardiness and woodiness to the fruits making them unusable in fresh condition [16]. This phenomenon from our study is time dependent and hence the object of the study which had sought to identify the time required for the different genotypes studied $[17,18]$.
The local okra genotypes according to Ubi et al. $[12,17]$, Asaka awum, Agwu early, Etighi idok and Okpo-mbontam fruits lignified at a shorter time interval when compared to the improved genotypes NHAe-47-4 and the Perkins long pod. The phenomenon of fruit lignification in okra has remained a source of worry and concern to the local okra farmers in this agro-ecology and others. The phenomenon has been responsible for the undesired and underutilization of 'dried okra' which shows reduced nutritional and economic value when compared to fresh unlignified fruits $[12,19]$.

Emphasis should be geared towards the improvement of the local okra genotypes 'Etighi idok', 'Asaka awum', 'Agwu early' and 'Okpombontam' which are mostly used by the farmers as planting material in subsequent seasons [12,19]. Planned research efforts geared towards identifying the biochemical and physiological bioremediation using nutrient additives or any other soil or plant processes is strongly advocated if food security and sustainability as well as increasing farmer's income and yield are our targets. Planned breeding programmes targeted at prolonging fruit lignification interval for this nutritious vegetable fruit is advocated [20,21].

The present study has thus provided the baseline information on fruit lignification time interval in only few okra genotypes. This provide a stepping stone towards the development of predictive model which can help put an end to the wastage of this important vegetable fruits due to the lignification biochemical and physiological processes in okra fruits.

\section{CONCLUSION}

The results shows significant differences and influence of the bio-fertilizers on the total genomic DNA contents, fruit lignification time interval, growth characteristics and yield components.

It was found and concluded from the study that genomic DNA contents varies from $134.100 \mathrm{ng} / \mu \mathrm{l}$ in Agwu early in control plot to $175.600 \mathrm{ng} / \mu \mathrm{l}$ in $\mathrm{NHAe}-54-4$ treated with poultry droppings +Algae. Fruit lignification time interval was significantly $(p<0.05)$ influenced by the biofertilizers and varied between 3 days 6 minutes in Agwu early in the control plots to 8 days and 23 hours in NHAe 47-4 treated with poultry dropping + Alage. Plant height varied $(p<0.05)$ 
significantly and ranged from $14.13 \mathrm{~cm}$ in Agwu early in control plot to $44.34 \mathrm{~cm}$ in NHAe-47-4 treated with poutry droppings + Algae while number of fruits per plant also varied $(p<0.05)$ significantly and ranged between 12.57 fruits per plant in Agwu early in control plots to 24.30 fruits per plant in NHAe-47-4 treated with poultry droppings + Algae. Based on the findings of this study, it is recommended that poultry droppings + Algae bio-fertilizers should be applied at $0.5 \mathrm{~kg}$ $15 \mathrm{~kg}$ soil in order to prolong fruit lignification time in okra for planned harvesting, increased income and mechanization of okra harvesting.

\section{COMPETING INTERESTS}

Authors have declared that no competing interests exist.

\section{REFERENCES}

1. Singh RK. Effect of intercrop and N-P fertilization on performance of okra (Abelmoschus esculentus). Journal of Research, Birsa Agricultural University. 2007;13(1):41-44.

2. Betra VK, Singh J. Screening of okra varieties to yellow vein mosaic virus under field conditions. Vegetable Science. 2000; 27(2):192-97.

3. Chakraborti S. An alternative approach in the management of okra fruit borer. Journal of Applied Zoological Research. 2000;12(1):47-51.

4. Asiegbu JE. Effects of organic manure substrate sources and time of photosynthetic sink of flower and pod production in Okra (Abelmoschus esculentus). East African and Forestry Journal. 1987;52(4):293-297.

5. Bhatt RM, Rao NK. Source manipulation induced variation in dry matter accumulation in sink of okra. Indian Journal of Horticulture. 2002;59(1):57-61.

6. De-Lannoy G, Romain HR. Crop production in tropical Africa. London McGraw Hills Publishers Ltd. N.Y. 2001;234-245.

7. Shrethra GK. Effect of spacing and Nfertilizer pusa sawani okra (Abelmoschus esculentus L. Moench) in Nepal. Experimental Agriculture.1983;19:239-242.

8. Dirshift $A L$, Lal OP, Srivastava YN. Persistence of pyrethroid and nicotinyl insecticides on okra fruits. Pesticides Research Journal. 2000;12(2):227-231.

9. Encyclopedia of fruits. Healthy recipes. Education and Healthy Library. 2013;2: 200.

10. Kaul K, Greer EC, Kasperbauer MJ, Mahl C. Row-row orientation effect on fruit yield and field-grown okra. Journal of Sustainable Agriculture. 2012;17(2-3):169174.

11. Muhammad A, Ayum MA, Ali A. Effect of phosphorus and planting density in seed production in okra (Abelmoschus esculentus). International Journal of Agriculture and Biology. 2001;3(4):380383.

12. Ubi GM, Onabe MB, Ubi W, Jemide OJ, EssienIS. Preliminary studies on fruit lignification time interval and phenological traits of selected okra (Abelmoschus esculentus $L$ Moench) genotypes grown in Southern Nigeria. International Journal of Plant and Soil Science (IJPSS). 2017; 10(2):1-10.

13. Muhammad A, Ayum MA, Ali A. Impact of phosphorus and planting geometry on growth, yield and quality of green pods in okra (Abelmoschus esculentus $L$ Moench). International Journal of Agriculture and Biology.2000;3(5):340-344.

14. Olasantan FO, Aina BJ. Effect of intercropping and population density on the growth and yield of okra (Abelmoschus esculentus L Moench). Betrage Zur Tropichenn Landwirtshaff and Veterinarmedizin. 1987;25(3):289-294.

15. Romain ME. Fruit lignification in okra. Experimental Agriculture. 2011;16:122125.

16. Supara S, Mukherirji S. Season-dependent mineral accumulation in fruits of okra and tomatoes. Journal of Environmental Biology. 2002;23(1):47-50.

17. Ubi GM, Onabe MB, Kalu SE. Path coefficient analysis, character association and variability in selected maize (Zea mays L) genotypes grown in Southern Nigeria. Annual Research \& Review in Biology. 2019;33(6):1-6.

18. This day Nigerian Newspaper. Agriculture and benefits of okra. 2001;8-9.

19. Verma IM, Batra BR. Effect of irrigation and nitrogen on growth and yield of okra. South Indian Horticulture.2001;49:386388 . 
20. Kumawatt RL, Parck B, Sharma A. Resistance of monocrotophos in okra fruits at harvest time. Annals of Agricultural Biological Research. 2009;5(2):165-176.
21. Muoneke CO, Asiegbu JE. Evaluation of growth and yield advantage of okra and cowpea sown in mixture. Journal of Agricultural Technology. 1999;7(1):18-25.

(c) 2020 Akpan et al.; This is an Open Access article distributed under the terms of the Creative Commons Attribution License (http://creativecommons.org/licenses/by/4.0), which permits unrestricted use, distribution, and reproduction in any medium, provided the original work is properly cited.

Peer-review history:

The peer review history for this paper can be accessed here:

http://www.sdiarticle4.com/review-history/55170 